Győrffy Zsuzsa* - Mészáros Eszter - Ádám Szilvia - Kopp Mária

\title{
AZ EGÉSZSÉGÜGYBEN DOLGOZÓ NŐK GYERMEKVÁLLALÁSSAL ÉS TERHESSÉGGEL KAPCSOLATOS MUTATÓI ORSZÁGOS REPREZENTATÍV MINTA ALAPJÁN
}

Célkitûzés: Magyarországon az egészségügyben dolgozók morbiditási és mortalitási mutatói az összlakosságénál kedvezőtlenebbek. Hipotézisünk szerint a mutatók alakulásának hátterében az egészségügyben dolgozók speciális stresszterhelése áll. Jelen vizsgálatunk az egészségügyben dolgozó diplomás nók terhességgel és szüléssel kapcsolatos mutatóinak vizsgálatát tưzte ki céljául.

Módszer: Országos, reprezentatív, 12643 főre kiterjedô kvantatív vizsgálat, amely kor, nem, településtípus szerint reprezentálja a magyar lakosságot. A vizsgált alminta: 132 egészségügyben dolgozó diplomás nó.

Eredmények: Az egészségügyben dolgozó diplomás nók körében nagyobb arányú volt a veszélyeztetett terhességek, meddóségi és teherbeesési problémák aránya, valamint az abortuszszám. A terhespatológiai esetek és a munkastressz kapcsolata szignifikáns összefüggést mutatott. A munkastressz rizikótényezóje mellett a társas támogatás hiánya, a házassági stressz, valamint a fizikai abúzus mutatott jelentôs összefüggést a vizsgált problémákkal.

Konklúzió: A kérdés vizsgálata felhívja a figyelmet az egészségügyi dolgozók fokozott veszélyeztetettségére. Kutatási eredményeink megerősítik, hogy a munkakörnyezeti tényezôk javítása elsôdleges a további prevenció szempontjából.

Kulcsszavak: reprodukciós zavarok, munkastressz, szerepkonfliktus

Az egészségügyben dolgozók hivatásbeli megterhelése óriási. A fizikai és pszichológiai teher, a hivatás és a családi szerepek összeegyeztethetóségéért kifejtett erôfeszítés és a financiális nehézségek egymást erósítő faktorokként hatnak. A nemzetközi szakirodalommal összhangban valószínúsíthető, hogy az orvostársadalom összlakosságnál kedvezótlenebb mortalitási és morbiditási adatainak hátterében a hivatás stresszorai állnak (Firth-Cozens 2003; Gautam 2001; Molnár és Mezey 1991; Bowman és Allen 1990). A magyarországi helyzettel szemben - ahol az orvosok egészségmutatói még a kimagaslóan rossz összlakossági arányoknál is kedvezótlenebb képet mutatnak - Nyugat-Európában és az Egyesült

\footnotetext{
* Levelezó szerző:

Győrffy Zsuzsa, Semmelweis Egyetem, Magatartástudományi Intézet 1089 Budapest, Nagyvárad tér 4.

E-mail: gyorzsu@net.sote.hu
} 
Államokban az orvosok szomatikusan egészségesebbek, mentálisan azonban betegebbek az átlagpopulációnál. A nemzetközi szakirodalmi adatok egybehangzóan az orvosok magas öngyilkossági veszélyeztetettségét jelzik (Arnetz és mtsai 1987; Boxer és mtsai 1995; Tyssen és mtsai 2001).

Jelen vizsgálatunk alapját korábbi kutatásaink képezték (Győrffy és Ádám 2003; Ádám és Győrffy 2003). Előző eredményeink azt mutatták, hogy az orvosnők egészségi állapotának és egészségmagatartásának mutatói között kiemelt szerepe van a terhességgel és gyermekvállalással kapcsolatos egészségügyi problémáknak (spontán vetélés, veszélyeztetett terhesség, meddőség, múvi abortusz - továbbiakban: egészségi problémák). 2002 ôszén végzett mélyinterjús kutatásunkban nyilvánvalóvá vált, hogy a terhességgel, szüléssel kapcsolatos problémák a megkérdezett orvosnók mintegy $74 \%$-ra jellemzók. Feltételezhetó, hogy az orvosi hivatás kritikus szakaszainak egyike a pályakezdés, amely a családalapítással és a munkastresszel együtt - mintegy egymást erősítve - hatnak a terhességekre, szülésekre (Phillips 2000; Levey 2001; Palepu és Herbert 2002).

Jelen tanulmányunk kísérletet tesz a kérdés még alaposabb áttekintésére. A Semmelweis Egyetem Magatartástudományi Intézetének 2002ben folytatott országos, reprezentatív, 12643 fốre kiterjedó Hungarostudy-vizsgálatának az egészségügyben dolgozó diplomás nókre vonatkozó eredményeit tesszük most közzé.

\section{MINTA ÉS MÓDSZEREK}

A Hungarostudy 2002 országos felmérés a 18 év feletti lakosságot reprezentálja, nem, kor és lakóhely szerint. A vizsgálat keretén belül 12643 személy kikérdezése történt meg. A magyar népesség egészségi állapotára irányuló felmérés a különbözố betegségek előfordulási gyakoriságára, rizikótényezóire, valamint az életminóség-mutatókra vonatkozóan reprezentatívnak mondható (Rózsa és mtsai 2003). A statisztikai elemzést az SPSS 9.0 program segítségével végeztük el, használt módszereink: független mintás T-próba, Khi-négyzet próba, esélyhányados. A szignifikancia szintjét a $\mathrm{p}=0,05$ jelentette.

\section{A minta leírása}

A fent bemutatott teljes mintából kutatásunkhoz az egészségügyben dolgozó diplomás nôk alcsoportját emeltük ki (továbbiakban: minta). 132 fó került a mintába, reprezentálva a magyarországi orvosnóket, gyógysze- 
résznôket, védőnóket, diplomás ápolókat és egyéb felsőfokú végzettségú egészségügyi dolgozókat.

A résztvevók életkora 20 és 80 év között van (az átlag 49 év), 65,9\%uk házastársi, illetve élettársi kapcsolatban él, 12,9\%-uk egyedülálló, 12,1\% az elváltak aránya, özvegy 9,1\%. A minta 40,8\%-ának 2 gyermeke van, 20,8\%-nak 1 gyermeke van, és ugyanennyinek nincsen gyermeke. 10,8\%-nak 3 gyermeke van, míg 4 vagy több gyermekkel 6,8\%-uk rendelkezik.

1. táblázat. Szociodemográfiai jellemzók

\begin{tabular}{|l|c|c|}
\hline Változók & $\begin{array}{c}\text { Egészségügyi dolgozók } \\
\mathrm{n}(\%)\end{array}$ & $\begin{array}{c}\text { Diplomás kontrollcsoport } \\
\mathrm{n}(\%)\end{array}$ \\
\hline Teljes minta & $132(13,6)$ & $838(86,4)$ \\
\hline $\begin{array}{l}\text { Életkor } \\
<30\end{array}$ & $14(10,6)$ & $145(18)$ \\
$30-39$ & $32(24,2)$ & $203(25,2)$ \\
$40-49$ & $30(22,7)$ & $207(25,5)$ \\
$50-59$ & $31(23,6)$ & $142(17,5)$ \\
$\geq 60$ & $25(18,9)$ & $115(13,8)$ \\
\hline $\begin{array}{l}\text { Házas/élettársi } \\
\text { kapcsolatban él }\end{array}$ & & $520(62)$ \\
Igen & $87(65,9)$ & $318(38)$ \\
Nem & $45(34,1)$ & $201(24,6)$ \\
\hline Gyerekszám & & $216(26,5)$ \\
Nincs & $27(20,8)$ & $325(39,8)$ \\
Igen & $27(20,8)$ & $55(6,8)$ \\
1 & $53(40,8)$ & $18(2,3)$ \\
2 & $14(10,8)$ & \\
3 & $9(6,8)$ & \\
$\geq 4$ & & \\
\hline
\end{tabular}

A jelenlegi aktivitás szempontjából a minta a következó képet mutatja (leszámítva két fốt, akik nem válaszoltak az adott kérdésre): 78 (60\%) közalkalmazott, 5 (3,8\%) alkalmazott, 13 (10\%) vállalkozó, 20 (15,4\%) nyugdíjas, 2 (1,5\%) rokkantnyugdíjas, 2 (1,5\%) háztartásbeli és 10 (7,8\%) GYED-en, illetve GYES-en lévő nô található közöttük. 


\section{Hipotézisek}

- Hipotézis 1: Feltételezésünk szerint az egészségügyben dolgozó diplomás nók egészségmutatói eltérnek a többi ágazatban dolgozókétól. Az egészségi állapot vizsgálatán belül kiemelt jelentôségú az anyaság egészségügyi dimenzióinak a leírása. A terhesség(ek), szülés(ek), illetve a gyermekvállalás mutatóinak fókuszba helyezése a korábbi mélyinterjús vizsgálatunk alapján lett kiemelt jelentőségú.

- Hipotézis 2: Hipotézisünk szerint az egészségi problémák hátterében a munkastressz okozta speciális megterhelések állnak. Korábbi vizsgálataink megerósítik ugyanakkor azt is, hogy a hivatás és a család összeegyeztetésének nehézségei szintén a morbiditást növelô tényezôként hatnak, fóképpen az orvosnók esetében (Ádám és Gyôrffy 2003).

- Hipotézis 3: A munkastressz és a gyermekvállalás, illetve a patológiás terhességek összefüggésének áttekintésén túl szükséges a problémák hátterében húzódó egyéb tényezôk leírása is. Nem hagyható figyelmen kívül a társas támogatás, a házassági stressz, a fizikai abúzus és a vizsgált személyek kora gyermekkori traumatizáló tényezóinek (szülók halála, válása, tartós távolléte a családtól stb.) vizsgálata sem. Hipotézisünk szerint a gyermekvállalás tényezóit a munkastressz hatása mellett számos pszichoszociális tényezó is befolyásolja.

\section{EREDMÉNYEK}

\section{Gyakorisági adatok}

Kutatásunkat a Hungarostudy 2002 felmérés terhességgel, szüléssel kapcsolatos kérdéseinek vizsgálatával kezdtük. Öt változót használtunk fel. Ezeket a változókat más ágazatokban dolgozó diplomás nók adataival összevetve az alapmegoszlások alapján elmondható, hogy a veszélyeztetett terhesség, a meddóség, az abortusz, illetve a sikertelen próbálkozás teherbe esésre változók esetében az egészségügyben dolgozó nók csoportja adta a legmagasabb értéket (2. táblázat). 
2. táblázat. A terhességgel, szüléssel kapcsolatos eredmények

\begin{tabular}{|l|c|c|}
\hline $\begin{array}{l}\text { Terhességgel, szüléssel } \\
\text { kapcsolatos kérdések }\end{array}$ & $\begin{array}{c}\text { Egészségügyben } \\
\text { dolgozók (\%) }\end{array}$ & $\begin{array}{c}\text { Nem egészségügyben } \\
\text { dolgozók (\%) }\end{array}$ \\
\hline Spontán vetélés & 8,0 & 12,0 \\
Veszélyeztetett terhesség & 12,0 & 11,0 \\
Sikertelen próbálkozás egy évig & 20,5 & 15,1 \\
Meddóség & 5,6 & 2,1 \\
Múvi abortusz & 27,9 & 23,2 \\
\hline
\end{tabular}

\section{Összefüggések a munkából fakadó stresszel}

Kapott eredményeink tehát első hipotézisünket megerôsítették. További feltételezésünk szerint az anyasággal kapcsolatos egészségi problémák változását a munkastressz eróssége is meghatározóan befolyásolja. Így a következő lépésben azt vizsgáltuk meg, milyen jellegú munkastresszról beszélhetünk az egészségügyben dolgozó nók esetében. Készítettünk egy munkastressz-indexet, amely a munkavégzés különböző aspektusait volt hivatva mérni. A munkastressz-index a következő elemekból áll (4 kérdés, 1 állítás):

- Jelenleg hány munkahelye van?

- Hány múszakban dolgozik?

- Fófoglalkozású munkáján kívül folytat-e más keresó tevékenységet?

- Hatottak-e Önre munkahelyén káros anyagok az elmúlt 10 évben?

- Elégedetlen vagyok anyagi helyzetemmel.

Mindezek alapján megvizsgáltuk, hogyan alakul a különbözó ágazatok között a munkastressz-terhelés. A kapott statisztikai adatok megerósítették hipotézisünket: a kétoldali T-próba szignifikáns kapcsolatot mutatott ki $(\mathrm{p}<0,001)$ a munkastressz és az anyasággal kapcsolatos egészségi mutatók között. Az egészségügyben és a nem egészségügyben tevékenykedó csoportok közötti szignifikáns különbség életkorra kontrollálva is megmarad. Az egészségügyben dolgozók esélye a munkastresszre majdnem kétszerese volt a nem egészségügyben dolgozó diplomás nókének $(\mathrm{OR}=1,971$ és $\mathrm{CI}=1,296-2,996)$.

A munkastressz-index kérdései közül a „Hány múszakban dolgozik?” és az „Elégedetlen vagyok anyagi helyzetemmel” itemek esetében a kétoldali T-próba szignifikáns kapcsolatot mutatott az egészségügyben dolgozók esetében (0,001, ill. 0,029). Az index ezen két eleme tehát a legmeghatározóbb jelentôségủnek bizonyult. 


\section{Munkával kapcsolatos attitúdök}

A Hungarostudy 2002 kérdőív egyik kérdésköre a munkával kapcsolatos szempontok értékelése volt. A munkastressz problémájának vizsgálatakor magától értetődónek túnt az egészségügyi dolgozók munkával kapcsolatos attitúdjeinek vizsgálata. A 3. táblázat azt mutatja, hogy az egészségügyben dolgozó diplomás nók egy 1-5-ig tartó skálán az alábbi változók közül milyen arányban jelölték meg a legmagasabb értéket a más ágazatban dolgozó diplomás nókhöz képest. Kapott eredményeink alapján a válaszok egyrészt kifejezik az érintettek felé közvetített társadalmi elvárásokat („,a társadalom számára hasznos munka”, „felelősségteljes munka"), másrészt pedig a megkérdezettek elképzeléseit tükrözik arról, mely tényezók hiányoznak leginkább a jelenlegi munkafeltételeik közül (, ,jó fizetés”, ,kötetlen munkabeosztás”, ,, sok szabadság”, "nagy megbecsülésnek örvendó munka"). Azt, hogy az egészségügyben dolgozók stresszterhelésének talán legjelentősebb faktora a munkaidô ritmusa és mennyisége, bizonyítja az is, hogy a legerősebben szignifikáns összefüggést a munkával kapcsolatos attitúdök és az ágazatok vizsgálatakor csak a „,kötetlen munkabeosztás” kérdésének vizsgálatakor kaptunk ( $\mathrm{p}<0,001)$.

3. táblázat. Munkával kapcsolatos attitûdök

\begin{tabular}{|l|c|c|}
\hline $\begin{array}{l}\text { Munkával kapcsolatos } \\
\text { attitúdök }\end{array}$ & $\begin{array}{c}\text { Egészségügyben } \\
\text { dolgozó diplomás nók (\%) }\end{array}$ & $\begin{array}{c}\text { Más ágazatban } \\
\text { dolgozó diplomás nók (\%) }\end{array}$ \\
\hline Jó fizetés & 67,2 & 63,4 \\
\hline $\begin{array}{l}\text { Kellemes emberekkel dolgozni } \\
\text { együtt }\end{array}$ & 64,8 & 66 \\
\hline Biztonságos munkahely & 72 & 67,6 \\
\hline Jó előrejutási lehetôség & 23,2 & 28,2 \\
\hline Jó idóbeosztás & 40 & 32,2 \\
\hline $\begin{array}{l}\text { Lehetóség a kezdeményezó- } \\
\text { készség kihasználására }\end{array}$ & 34 & 33 \\
\hline $\begin{array}{l}\text { A társadalom számára hasznos } \\
\text { munka }\end{array}$ & 41 & 36 \\
\hline Sok szabadság & 33 & 28 \\
\hline Találkozni lehet emberekkel & 43 & 29 \\
\hline $\begin{array}{l}\text { Olyan munka, aminél úgy érzi, } \\
\text { megvalósít valamit }\end{array}$ & 55,2 & 55,8 \\
\hline Felelősségteljes munka & 52 & 44,2 \\
\hline Érdekes munka & 62,9 & 52,6 \\
\hline Kötetlen munkabeosztás & 46,2 & 23,6 \\
\hline
\end{tabular}




\section{A munkastressz és az anyaság egészségi mutatóinak összefüggései}

Az egészségügyben dolgozó diplomás nók munkastressze tehát magasabb, mint az egyéb ágazatokban dolgozó diplomás nóké. Az egészségügyben dolgozók esetében a munkastressz és az anyaság egészségi tényezóivel való összefüggést a 4. táblázat szemlélteti.

4. táblázat. A munkastressz és az egészségi mutatók összefüggései

\begin{tabular}{|l|c|c|c|}
\hline $\begin{array}{l}\text { Anyasággal kapcso- } \\
\text { latos egészségügyi } \\
\text { történések }\end{array}$ & $\begin{array}{c}\text { Szignifikanciaszint } \\
\text { kétoldali T-próbával }\end{array}$ & Esélyhányados & $\begin{array}{c}95 \% \text {-os konfiden- } \\
\text { cia-intervallum }\end{array}$ \\
\hline $\begin{array}{l}\text { Sikertelen próbál- } \\
\text { kozás teherbeesésre }\end{array}$ & $\begin{array}{c}0,073 \\
\text { (jelzi a tendenciát) }\end{array}$ & ----- & ------- \\
\hline Meddóség & 0,016 & 3,357 & $1,207-9,337$ \\
\hline Abortusz & 0,013 & 1,550 & $1,094-2,199$ \\
\hline
\end{tabular}

A munkastressz és a terhespatológiai történések elemzése azt mutatja, hogy a nagy munkastresszú egészségügyi ágazatokban dolgozó nók háromszor nagyobb eséllyel meddók, illetve másfélszer több eséllyel végeztetnek abortuszt, mint a nem az egészségügyben dolgozó nók. A vizsgált csoportnál a munkastressz nem hat a spontán vetélésekre és a veszélyeztetett terhességek alakulására. Azok a stresszorok, amelyek a munkán keresztül hatnak, döntően a gyermekvállalás prevalenciáját határozzák meg.

\section{Az anyaság egészségi körülményeit befolyásoló egyéb háttértényezók az egészségügyben dolgozó diplomás nók esetében}

Az egészségügyben dolgozó nók terhességgel, szüléssel kapcsolatos egészségügyi mutatóinak vizsgálatakor arra is választ kerestünk, hogy a munkastressz mellett milyen egyéb tényezókkel tárható fel összefüggés. A gyermekvállalással kapcsolatos kérdések áttekintésekor ugyanis nem hagyható figyelmen kívül a házassági/élettársi kapcsolat és a társas támogatás alakulása. A szakirodalmi adatok alapján feltételeztük azt is, hogy a leendó anyák korai kötődési zavarai és a fizikai abúzusok elófordulása összefüggenek a terhességi morbiditással (Fojtyik és mtsai 1999; Ney és Wickett 1993). 
A terhességek esetén, a gyermekszüléskor és a gyermekvállaláskor kulcsfontosságú, hogy a fiatal nô számíthat-e valakire ezekben az időszakokban. Egy gyermek vállalása vagy a terhesség megszakítása számos tényezótól függ, s a kapott adatok alapján a munkakörülmények és a munkastressz mellett a társas kapcsolatok alakulása is döntô tényezőnek bizonyult. Mint azt az 5. táblázatban láthatjuk, a társas támogatás rendszerén belül a kollegiális támogatás tényezói nem függtek össze a vizsgált problémákkal, s ez egyben jelezheti azt is, hogy a munkastressz - mint ahogyan ezt már az előzőekben feltételeztük - elsósorban a „külső” intézményi, illetve strukturális tényezókkel függ össze, nem a munkatársi támogatás hiányával.

5. táblázat. A társas támogatás hiánya mint a terhességmegszakítás rizikófaktora

\begin{tabular}{|l|c|c|c|}
\hline $\begin{array}{l}\text { Társas támogatás } \\
\text { hiánya }\end{array}$ & Szülő részérôl & Partner részéról & $\begin{array}{c}\text { Munkatársak } \\
\text { részéról }\end{array}$ \\
\hline $\begin{array}{l}\text { Veszélyeztetett } \\
\text { terhesség }\end{array}$ & nem szignifikáns & nem szignifikáns & nem szignifikáns \\
\hline Meddôség & nem szignifikáns & nem szignifikáns & nem szignifikáns \\
\hline Abortusz & $0,026(\mathrm{OR}=3,088$ & $0.038(\mathrm{OR}=2,888$ & nem szignifikáns \\
& $\mathrm{CI}=1,222-7,801)$ & $\mathrm{CI}=1,105-7,544)$ & nem szignifikáns \\
\hline $\begin{array}{l}\text { Sikertelen } \\
\text { próbálkozás 1 évig }\end{array}$ & nem szignifikáns & nem szignifikáns & \\
\hline
\end{tabular}

A gyermekvállalás/nevelés, a terhességek, illetve a terhességmegszakítás esetén a partner szerepe a társas támogatás rendszerén belül is kiemelt szerepú. Nem hagyhattuk tehát figyelmen kívül a házassági stressz szerepét sem, melyet a következó kérdések alapján, indexet készítve állítottunk eló:

- Házastársa (élettársa) az Önhöz legközelebb álló személy, a bizalmasa?

- Vannak-e olyan dolgok, amikról nem tudnak nyíltan beszélgetni egymással?

- Voltak korábban komoly problémák a kapcsolatukban?

- Problémáikat közösen szokták megoldani?

- Házastársával (élettársával) közösen töltik a szabadidejüket?

Amint az a 6. táblázatban látható, a házassági stressz - a munkastresszhez hasonlóan - elsősorban a gyermekvállalás melletti döntés valószínúségét határozta meg. Mint azt fentebb láttuk, a biztos családi kötelékek hiánya vagy nem elégséges volta ezen a téren szintén döntô jelentôségú.

Eredményeink alapján elmondható továbbá az is, hogy a fizikai abúzusnak (a bántalmazásnak a partner, illetve korábban a szülók részéról) 
6. táblázat. A házassági stressz hatása

\begin{tabular}{|l|l|}
\hline Házassági stressz (faktor) & \multicolumn{1}{|c|}{ Szignifikanciaszint } \\
\hline Veszélyeztetett terhesség & nem szignifikáns \\
\hline Meddőség & nem szignifikáns \\
\hline Abortusz & $0,009($ OR $=1,741 e ́ s ~ C I=1,152-2,631)$ \\
\hline Sikertelen próbálkozás teherbe esésre 1 évig & nem szignifikáns \\
\hline
\end{tabular}

igen lényeges szerepe volt a terhességmegszakítások, illetve a terhességek kimenetele szempontjából (7. táblázat).

A korai kötődés kérdésének vizsgálatakor nem találtunk összefüggést a gyermekvállalás, illetve a terhességpatológiai esetek között: a szülók válásának, halálának, illetve a vizsgált személy 1 éves kor elótti, családtól való tartós távollétének a vizsgált paraméterekre gyakorolt hatása nem volt kimutatható.

7. táblázat. A bántalmazás és a terhességi problémák összefüggései

\begin{tabular}{|l|l|}
\hline Bántalmazás a partner részéról & \multicolumn{1}{|c|}{ Szignifikanciaszint } \\
\hline Veszélyeztetett terhesség & $0,008(\mathrm{OR}=10,154 ; \mathrm{CI}=2,040-50,531)$ \\
\hline Meddóség & nem szignifikáns \\
\hline Abortusz & $\mathrm{p}<0,001$ \\
\hline Sikertelen próbálkozás teherbe esésre 1 évig & nem szignifikáns \\
\hline & \\
\hline Bántalmazás a szülő részéról & \\
\hline Szignifikanciaszint & \\
\hline Veszélyeztetett terhesség & $0,008(\mathrm{OR}=5,636 ; C I=1,685-18,851)$ \\
\hline Meddôség & nem szignifikáns \\
\hline Abortusz & nem szignifikáns \\
\hline Sikertelen próbálkozás teherbe esésre 1 évig & nem szignifikáns \\
\hline
\end{tabular}

\section{KÖVETKEZTETÉSEK}

Vizsgálatunk eredményei azt mutatják, hogy az egészségügyben dolgozó diplomás nók anyasággal kapcsolatos egészségi mutatóinak alakulását számos szociológiai és pszichológiai tényezó kölcsönhatása határozza meg.

Az egészségügyben dolgozók speciális stressztôl szenvednek (Wall és mtsai 1997). A szakirodalom megállapításai és korábbi mélyinterjús vizsgálataink alapján elmondható, hogy a hosszú munkaidô, a nagyfokú fi- 
zikai és pszichés megterhelés, valamint a financiális nehézségek (amelyek sok esetben túlmunkához vezetnek) egymást erősító tényezókként hatnak az egészségügyben dolgozók esetében (Sonneck 1992).

A munka stresszorain kívül a nagyfokú fizikai megterhelés, illetve a tartós kimerültségi állapot is hozzájárul az egészségügyi dolgozók testilelki problémáinak alakulásához. A munka és a pihenés arányának szervezeti szabályozása alól az egészségügyi szakmák általában kivételt képeznek (Weinger és Ebden 2002). Az orvosi szakma legtöbb területére az jellemzó, hogy a napi és a heti munka elózetesen csak részben tervezhetô meg. Ez a tényezô jelentősen növeli a munkából adódó megterhelést. Sokan lemondanak munkájuk strukturálásáról, melynek következményeképpen a munkájuk „tervezi meg” mindennapjaikat. A személyes igények háttérbe szorulnak, növelve az egyénre nehezedő pszichés nyomást.

Az egészségügyben dolgozók stresszterhelésének vizsgálatakor tehát kiemelt szerepet kap a több múszakos (sok esetben 24 órás igénybevétellel járó), illetve a több színterú munkavállalás. Ez a fajta megterhelés különböző fizikai és pszichikai problémák indikátorává válhat, amellett, hogy a több múszakos munkavégzés a társas kapcsolatokat és a családi élet szervezését is megnehezíti (Pikó és Piczil 2000). Mindezek a tényezók fokozottan sújtják a nóket, hiszen a munka és a családi szerepek összeegyeztetésének terhével együtt élettanilag is nehezebben tolerálják a biológiai ritmus átrendezódését.

Emellett nem hagyhatók figyelmen kívül az egyéb pszichoszociális stresszorok, valamint a jelentós szerepkonfliktusok sem. A férjezett nóknek, különösen a kisgyermekeseknek jelentốs problémáik vannak a családi és foglalkozásbeli kötelezettségeik ellátásában, s ez gyakran frusztrációhoz, kimerültséghez és megbetegedésekhez vezet.

A munkakövetelmények és a családi felelôsség kettôs szerepterhelést eredményez, mely az egészségügyben dolgozók - különösen az orvosnók - esetében jelentôsen megnehezíti a szimultán egyeztetést. Ez a szerepfeszültség a gyermekvállaláskor a legjelentôsebb hatású, de végigkíséri óket egész életpályájukon (Firth-Cozens 1997; Hsu és Marshall 1997). Feltételezhetó továbbá az is, hogy a pályakezdés stresszorai döntô hatással bírnak a gyermekvállalásra. A munkavégzés körülményeinek jellege (ügyeletek, alváshiány, a magánéletre jutó idő mennyisége, a munkatapasztalat hiánya és az ebból fakadó szorongás, valamint a pénzügyi nehézségek) és a házassági/élettársi kapcsolatok problémái (idóhiány, kommunikációs zavarok, financiális problémák, a háztartási teendók megosztásának kérdése, szexuális problémák) kölcsönösen hatnak egymásra, felerősítik egymást (Bowman és Allen 1990). 
A nemzetközi szakirodalom egyöntetú álláspontja szerint a munkával kapcsolatos stresszorok és az egészségi állapot között szoros összefüggés figyelhetó meg. Kimutatható ugyanis, hogy a hosszú munkaidó és a nagyfokú érzelmi és fizikai megterhelés a nók esetében gyakrabban vezet szívkoszorúér-megbetegedésekhez, valamint miokardiális infarktushoz (Haynes és Feinleib 1980; Haynes és mtsai 1984; Theorell 1991).

A speciális stresszterheléssel összefüggésben a kutatók a terhességi problémák arányát is kiemelkedónek találták. Svéd vizsgálatok kimutatták, hogy a túlmunka és a változó idóbeosztás nagyobb valószínúséggel okoz vetélést (Axelsson és mtsai 1989). Ez az arány még számottevơbb akkor, ha a terhes nônek már van(nak) gyermeke(i). Kanadai kutatók bebizonyították, hogy az esti, illetve az éjszakai idóbeosztás 3-4-szeresére növeli a spontán vetélések arányát (Infante-Rivard és mtsai 1993).

Vizsgálatunkban kimutattuk, hogy a többi ágazatban dolgozó diplomás nókhöz viszonyítva mintánkban a legnagyobb a veszélyeztetett terhességek, a meddôségek és az abortuszok száma.

Kimutattuk továbbá azt is, hogy az egészségügyben dolgozó diplomás nôk munkastressze szignifikáns többletet mutat a más ágazatokban dolgozókéhoz képest. Ugyanakkor megállapítható volt, hogy a munkastressz és az anyaság egészségi mutatóinak összefüggése az eredeti hipotézistól kismértékben eltér. A munkastressz nem elsósorban a terhességek kimenetelét, a terhességi problémákat valószínúsítette, hanem a gyermekvállalást. Azok a stresszorok tehát, amelyek a munkán keresztül hatnak az egészségügyben tevékenykedô diplomás nôkre, döntôen meghatározták, hogy miként alakult a gyermekvállalás.

A munkastressz mellett számos más tényezó hatását sem lehetett figyelmen kívül hagyni. Az abortuszok esetén a szociális támogatás hiánya, a házassági stressz mértéke és az elszenvedett bántalmazás egymást erôsító faktorokként hatottak. A fizikai abúzus az abortuszok gyakoriságát és a veszélyeztetett terhességet befolyásolta. A meddóségre azonban kizárólag a munkastressz volt hatással.

Kapott eredményeink alapján feltételezhetó, hogy a munka stresszorai, valamint a magánélet stresszorai egymást kölcsönösen felerôsítve hatnak az anyaság egészségi dimenzióira. Korábbi vizsgálatainkkal összhangban megállapítjuk továbbá azt is, hogy a munkastressz magánéletre gyakorolt hatása kulcsszerepú a terhespatológiai esetek elemzésekor.

A kérdés vizsgálata felhívja a figyelmet az egészségügyi dolgozók fokozott veszélyeztetettségére. Kutatási eredményeink megerósítik, hogy a munkakörnyezeti tényezók javítása elsődleges a további prevenció szempontjából. 


\section{Irodalom}

Arnetz, B. B., Hörte, L. G., Hedberg, A., Theorell, T., Allander, E., Malker, H. (1987): Suicide patterns among physicians related to other academics as well as to the general population. Acta Psychiatria Scandinavica, 75: 139-143.

Axelsson, G., Rylander, R., Molin, I. (1989): Outcome of pregnancy in relation to irregular and inconvenient work schedules. Br. J. Ind. Med., 46: 393-398.

Ádám Sz., Győrffy Zs. (2003): Orvosnók az anyaságról. Esély, 3: 86-92.

Boxer, P. A., Burnett, C., Swanson, N. (1995): Suicide and occupation: a review of the literature. Journal of Occup. Environ. Med., 37: 442-452.

Bowman, M. A., Allen, D. I (1990): Stress and Women Physicians. Springer-Verlag, New York, Berlin.

Firth-Cozens, J. (2003): Doctors, their wellbeing, and their stress. British Medical Journal, 326: $670-671$.

Firth-Cozens, J. (1997): Depression in doctors. In Robertson, M., Kantona, E. (eds.): Depression and Physical Illness. New York, 95-111.

Fojtyik I., Kiss K., Rózsa S. (1999): Fiatal nók szexuális életének egyes dimenziói: fogamzásgátlás, gyermekvállalás, terhességmegszakítás. Mentálhigiéné és Pszichoszomatika, 1 (3-4): 30-40.

Gautam, M. (2001): Women in medicine. Western Journal of Medicine, 174 (1): 37-41.

Győrffy Zs., Ádám Sz. (2003): Szerepkonfliktusok az orvosnói hivatásban. Lege Artis Medicinae, 13 (2): 159-164.

Haynes, S. G., Eaker, E. D., Feinleib, M. (1984): The effect of employment family and job stress on coronary heart disease patterns in women. In Gold, E. (ed.): The Changing Risk of Disease in Women. Health and Co., Lexington.

Haynes, S. G., Feinleib, M. (1980): Women work and coronary disease: prospective findings from the Framingham heart study. American Journal of Public Health, 70: 133-141.

Hsu, K., Marshall, V. (1997): Prevalence of depression and distress in a large sample of Canadian residents, interns and physicians. Psychiatr. Clin. N. A., 144: 1561-1566.

Infante-Rivard, C., David, M., Gauthier, R., Rivard, G. E. (1993): Pregnancy loss and work schedule during pregnancy. Epidemiology, 4: 73-75.

Levey, R. E. (2001): Sources of Stress for Residents and Recommendationsfor Programs to Assist Them. Academic Medicine, 76 (2): 142-150.

Molnár L., Mezey M. (1991): Az orvosok megbetegedéséról és halandóságáról. I-III. Lege Artis Medicinae, 1 (8): 524-528.; (9-10): 640-644.; (11): 966-970.

Ney, P., Wickett, A. R. (1993): Relationship between abortion and child abuse and neglect: four studies. Pre- and Perinatal Psychology Journal, 8 (1): 43-63.

Palepu, A., Herbert, C. P. (2002): Medical women in academia: the silences we keep. Journal of Canadian Medical Association, 167 (8): 877-879.

Phillips, S. P. (2000): Parenting, puppies and practise: juggling and gender in medicine. Journal of Canadian Medical Association, 162 (8): 663-672.

Pikó B., Piczil M. (2000): „És rajtunk ki segít...?” Kvalitatív egészségszociológiai elemzés a nôvéri hivatásról. Esély, 11 (1): 110-120.

Rózsa S., Réthelyi J., Stauder A., Susánszky É., Mészáros E., Skrabski Á., Kopp M. (2003): A Hungarostudy 2002 országos reprezentatív felmérés általános módszertana és a felhasznált tesztbattéria pszichometriai jellemzói. Psychiatria Hungarica, 18 (2): 83-94.

Sonneck, G. (1992): Orvosok öngyilkossága és kiégettsége. Szenvedélybetegségek, 2 (1): 28-31. 
Theorell, T. (1991): On cardiovascular health in women: results from epidemiological and psychological studies in Sweden. In Frankenheuser, M., Lundberg, U., Chesney, M. (eds.): Women, Work and Health. Plenum Press, New York, 187-204.

Tyssen, R., Vaglum, P., Gronvold, N. T, Ekeberg, O. (2001): Suicidal ideation among medical students and young physicians: a nationwide and prospective study of prevalence and predictors. Journal of Affective Disorders, 64: 69-79.

Wall, T. D., Bolden, R. I., Borill, C. S., Carter, A. J., Golya, D. A., Hardy, G. S., Haynes, C., E., Rick, J., E., Shapiro, D., A., West, M., A. (1997): Minor psychiatric disorders in NHS trust staff: occupational and gender difference. British Journal of Psychiatry, 171: 519523.

Weinger, M., Ebden, P. (2002): Sleep deprivation and clinical performance. JAMA, 287: 955-958.

\section{GYÔRFFY, ZSUZSA - MÉSZÁROS, ESZTER - ÁDÁM, SZILVIA - KOPP, MÁRIA \\ CHILDREARING AND REPRODUCTIVE INDICATORS AMONG FEMALE HEALTHCARE PROFESSIONALS IN HUNGARY: RESULTS FROM A NATIONWIDE REPRESENTATIVE SURVEY}

Background: Morbidity and mortality rates among health care professionals in Hungary are significantly higher than that of the general population. However, little is known about the reproductive health status of female healthcare professionals.

Aim: To explore reproductive morbidity among female healthcare professionals in Hungary.

Subjects and methods: Analysis of data obtained from 132 female healthcare professionals using the database of the Hungarostudy $2002(n=12.643)$, a nationwide representative survey on health status.

Results: We found a significantly higher prevalence reproductive morbidity including pathological pregnancies, infertility, difficulties in conception, and abortion among female healthcare professionals compared to women in other occupational strata. Maternal reproductive morbidity was significantly correlated with work stress, lack of social support system, marital discord and physical abuse.

Conclusion: Increased reproductive morbidity among female healthcare professionals in Hungary may be attributed to high levels of psychosocial stress associated with occupational and marital stressors/factors. Further analyses of such stressors are essential in devising effective preventive measures and decreasing reproductive morbidity.

Keywords: reproductive morbidity, work-related stress, role conflict 